\title{
SATELLITE-DERIVED \\ COASTAL OCEAN AND ESTUARINE SALINITY \\ IN THE MID-ATLANTIC
}

by

Erick Francis Geiger

A thesis submitted to the Faculty of the University of Delaware in partial fulfillment of the requirements for the degree of Master of Science in Marine Studies

Fall 2011

(C) 2011 Erick Francis Geiger

All Rights Reserved 


\section{SATELLITE-DERIVED \\ COASTAL OCEAN AND ESTUARINE SALINITY \\ IN THE MID-ATLANTIC}

by

Erick Francis Geiger

Approved:

Matthew J. Oliver, Ph.D.

Professor in charge of thesis on behalf of the Advisory Committee

Approved:

Charles E. Epifanio, Ph.D.

Director of the School of Marine Science and Policy

Approved:

Nancy M. Targett, Ph.D.

Dean of the College of Earth, Ocean, and Environment

Approved:

Charles G. Riordan, Ph.D.

Vice Provost for Graduate and Professional Education 


\section{ACKNOWLEDGMENTS}

I would like to thank the administration at the University of Delaware in

Lewes for making my time here a pleasant one. The encouraging attidue and atmosphere of the campus is unlike any other I have encountered. I also want to thank those students, past and present, who helped me feel welcome and guide me through my first year and of course, my lab mates with whom I've spent the majority of my time working (and laughing). Lastly, I would like to thank my advisor, Dr. Oliver, who has been an exceptional advisor both academically and in most areas of life. I certainly couldn’t ask for more pleasant people to work with. Thank you all.

The work in this thesis has been accepted for publication in Continental Shelf Research (Geiger et al., 2012). Much of the work described in this thesis appears there. The reference is as follows: Geiger, E.F., Grossi, M.D., Trembanis, A.C., Kohut, J.T., Oliver, M.J., 2012. Satellite-derived Coastal Ocean and Estuarine Salinity in the Mid-Atlantic. Continental Shelf Research. Accepted. 


\section{TABLE OF CONTENTS}

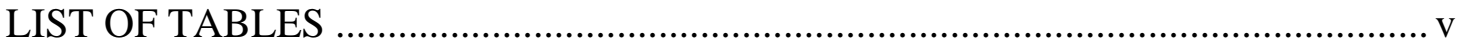

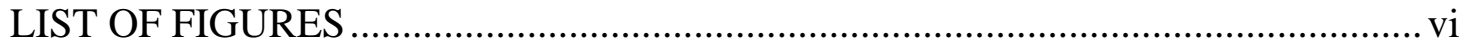

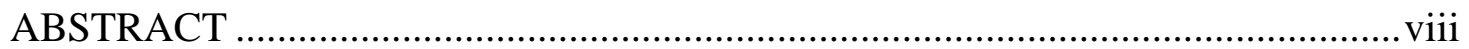

\section{CHAPTER}

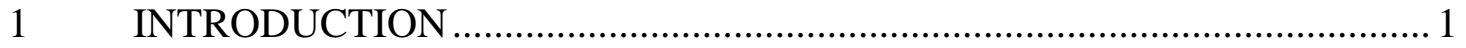

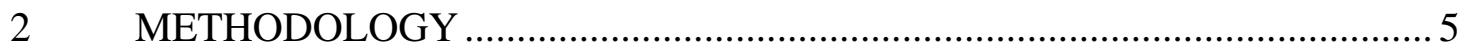

2.1. In situ Environmental Data...................................................................... 5

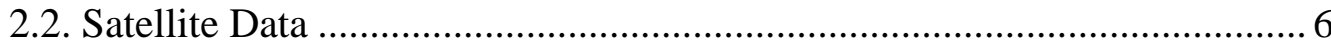

2.3. Satellite Matches .................................................................................. 7

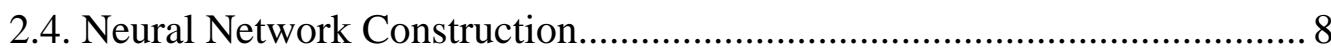

2.5. Climatological Data.............................................................................. 9

$3 \quad$ RESULTS

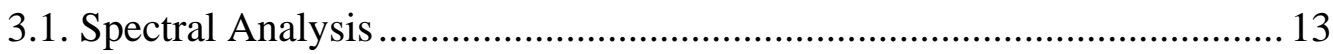

3.2. Neural Network Predictions ...................................................................... 14

3.3. Climatological Analyses........................................................................... 15

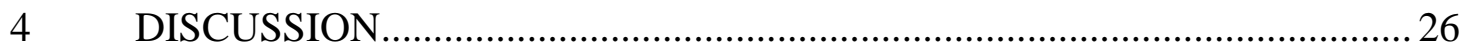

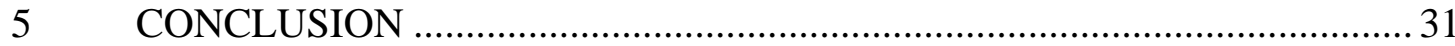

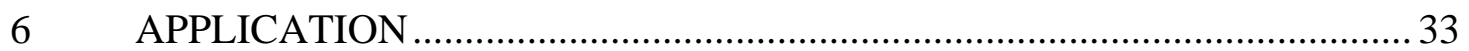

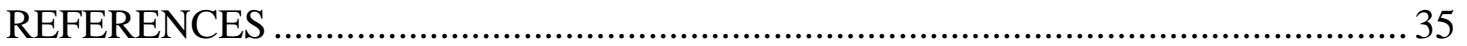




\section{LIST OF TABLES}

Table 3.1: $\quad$ Range and mean of satellite-matched in situ salinity data. ..................... 19

Table 3.2: Input parameters of optamized neural networks. The columns represent latitude, longitude, sea surface temperature $\left({ }^{\circ} \mathrm{C}\right)$, and normalized water-leaving radiance wavelengths and wavelength ratios at specified magnitudes in (nm). The rows indicate which model they are in.

Table 3.3: $\quad$ RMS and mean difference between NODC climatology and satellite-based Mid-Atlantic climatology............................................. 19 


\section{LIST OF FIGURES}

Figure 2.1: $\quad$ Spatial extent of in situ salinity data before (A) and after (B) satellite match-up. Boxes indicate sub-regions (from North to South: Hudson, Delaware, Chesapeake). Also shown are the locations of the Potomac River stream gauge (open circle) and the Lewes, DE tide station (open triangle). The matched dataset contains less than $1 \%$ of the original dataset.

Figure 2.2: $\quad$ Temporal distribution of satellite-matched in situ salinity data. Data in the Delaware and Chesapeake sub-regions are collected mostly in the late winter/early spring and late summer/early fall. Data for the Hudson sub-region only span April, May and June.

Figure 3.1: $\quad$ Spectral shape of water-leaving for the six wavelengths from MODIS-Aqua for the (A) Mid-Atlantic, (B) Chesapeake, (C) Delaware, and (D), Hudson sub-regions. The shapes of the spectra are colored by satellite-matched in situ salinity values where red is high salinity and blue is low salinity. Low salinity spectra have peak reflectance in the green wavelengths, while high salinity spectra have peak reflectance in blue wavelengths.

Figure 3.2: $\quad$ Model II regression of satellite-matched in situ salinity vs. model predicted salinity in the (A) Mid-Atlantic, (B) Chesapeake, (C) Delaware, and (D), Hudson sub-regions. All of the regressions are significant $(p<0.01)$. All of the models over predict salinity. The RMS errors for each are as follows: Mid-Atlantic $=2.29 \mathrm{psu}$, Chesapeake $=1.72 \mathrm{psu}$, Delaware $=1.97 \mathrm{psu}$, Hudson $=1.40 \mathrm{psu}$

Figure 3.3: Time series of rolling 32-day averaged stream flow in the Potomac River near Washington DC (gauge 01646500) and 32day averaged salinity at the mouth of the Potomac River (22 $\mathrm{x}$ $8.75 \mathrm{~km}$ box). There is a significant inverse pattern between stream flow and salinity, however the correlation between them is low $\left(\mathrm{R}^{2}=0.2, \mathrm{p}<0.01\right)$. 
Figure 3.4: Seasonal salinity climatologies for (A) winter, (B) spring, (C) summer, and (D) fall for the Mid-Atlantic model up to $50 \mathrm{~km}$ offshore. All seasons show characteristic coastally trapped river plumes. Winter and fall are generally fresher. Climatologies are mapped between 25 and 30 psu to emphasize differences between seasons.

Figure 3.5: Model II regression between the Mid-Atlantic model

climatologies and the NODC quarter-degree resolution climatologies for (A) winter, (B) spring, (C) summer, and (D) fall. Our satellite-based salinity models are significantly fresher than the existing climatologies. RMS errors for each are as follows: winter $=3.91 \mathrm{psu}$, spring $=1.89 \mathrm{psu}$, summer $=2.69 \mathrm{psu}$, fall $=$ 3.87 psu.

Figure 3.6: Between-season salinity ranges for (A) winter, (B) spring, (C) summer, and (D) fall calculated from the Mid-Atlantic model climatologies. Ranges were calculated by subtracting the minimum salinity value from the maximum salinity value for each grid point for the 6 years analyzed (2003-2008). Winter (A) has the largest salinity difference of the four seasons throughout the Mid-Atlantic while summer (C) has the least.

Figure 3.7: Annualized rate of salinity change for (A) winter, (B) spring, (C) summer, and (D) fall calculated from the Mid-Atlantic model climatologies. Annualized rates of change were calculated using linear regression models on each grid point for the 6 years analyzed (2003-2008). Only significant slopes $(\mathrm{p}<0.05)$ at each grid point were colored. Positive slopes are red and negative slopes are blue. Insignificant slopes are black to show the model domain. Trends in salinity range from -1 to $1 \mathrm{psu}$.

Figure 6.1: $\quad$ Salinity estimated from the Chesapeke Bay algorithm as seen on NOAA's coastwatch website. This image was produced on November 2nd, 2011. Salinity is in units of PSU. Red values are high salinity and blue values are low. 


\begin{abstract}
Coastal ocean salinity is a basic oceanographic property that is not routinely estimated by satellites. Efforts to measure ocean salinity from space are designed for large scale open ocean environments, not coastal regions. In the MidAtlantic coastal ocean, salinity is critical for understanding circulation patterns, river plumes, and transport, which in turn impact the status of the ecosystem. However, the spatial and temporal coverage of in situ salinity measurements in this region are sparse and do not synoptically capture salinity in the coastal ocean. I compiled $\sim 2$ million salinity records from four regional research vessels between the years 2003-2008 and found $\sim 9$ thousand salinity records that could be adequately matched to MODIS-Aqua data. I show that the spectral shape of water-leaving radiance and sea surface temperature are most correlated with in situ salinity. Four neural network models designed to predict salinity were developed for the Mid-Atlantic coastal region and three of its major estuaries (Hudson, Delaware, and Chesapeake). These models predict salinity with RMS errors between 1.40 psu and 2.29 psu, which are much less than the null model ranges (4.87-10.08 psu) and the natural range of the system (0-32 psu). Seasonal climatologies for the Chesapeake, Delaware, and Mid-Atlantic regions based on these models are fresher than the existing NODC climatologies. I also found significant freshening trends in the Mid-Atlantic over a 6 year period.
\end{abstract}




\section{Chapter 1}

\section{INTRODUCTION}

Sea surface salinity is the key tracer of freshwater input to coastal oceans and directly contributes to seawater density and circulation patterns. Estuaries are highly productive ecosystems that experience large salinity changes daily and seasonally. Many organisms within estuaries, such as larval and juvenile fishes, have different tolerances to salinity and are only found within certain ranges (Brooks, 2005; Kinne, 1983). For example, salinity zones of Chesapeake and Delaware Bays can be inferred from their local fauna (Bulger et al., 1993). Changes in salinity and temperature patterns also indicate where terrestrial and marine systems mix. This mixing distributes nutrients which impacts the production of the coastal ecosystem (Fisher et al., 1988; Johnson et al., 2003; Malone et al., 1988; Moline et al., 2008; Smith and Demaster, 1996). In the Mid-Atlantic region, modelers have adopted satellite-based sea surface temperature (SST) data to initialize circulation models that estimate the biogeochemical exchange between terrestrial and marine systems (Fennel et al., 2006; Wilkin et al., 2005). Providing satellite-based surface salinity information on the same spatial scale as SST could improve model predictions of coastal ocean currents and transport along and across the continental shelf (Wilkin et al., 2005, Lagerloef et al., 1995). Measuring sea surface salinity from a satellite in space has been seriously discussed in the past (Swift and Mcintosh, 1983) and more recent efforts are up and running such as NASA's Aquarius mission to improve the community's ability to map 
global ocean salinity (Lagerloef, 2008). Aquarius uses a microwave radiometer at 1.4 $\mathrm{GHz}$ ot measure salinity at an accuracy of $0.2 \mathrm{psu}$. Despite the great potential of Aquarius in the open ocean, the resolution of the satellite is on the order of $150 \mathrm{~km}$ and is too coarse to capture salinity structures that are typical of coastal and estuarine systems. Therefore, alternatives are needed to bring this critical observation into the coastal zone to advance the understanding of mixing and biogeochemical exchange between terrestrial and marine systems.

Many studies have found that detritus and colored dissolved organic material (CDOM) concentrations are good tracers of salinity (Coble et al., 2004; Del Vecchio and Blough, 2004; Vodacek et al., 1997). In the coastal ocean, a large portion of $\mathrm{CDOM}$ is terrestrial in origin and is therefore associated with fresh water (Opsahl and Benner, 1997). As high CDOM-low salinity water mixes with low CDOM-high salinity water, one would expect salinity to have an inverse relationship with CDOM concentration. CDOM also primarily absorbs light in the ultraviolet and blue portions of the spectrum making it an important control on the transfer of solar radiation through the water column and detectable by optical sensors (Siegel and Michaels, 1996; Siegel et al., 1995). Therefore, optical signals (absorption or reflectance) of coastal waters in the blue portions of the visible spectrum could be used as salinity proxies. For example, CDOM has been related to salinity through in situ ultraviolet optical measurements in waters off the west coast of Ireland (Monahan and Pybus, 1978). Additionally, an inverse relationship between salinity and CDOM exists in the Clyde Sea on the west coast of Scotland (Bowers et al., 2000). A similar linear relationship between ocean color and CDOM has been used to estimate salinity in the Clyde Sea (Binding and Bowers, 2003). Like the Mid-Atlantic Bight, the Clyde Sea is 
a broad shelf sea with large inputs of fresh water, but unlike the Mid-Atlantic, it is semi-enclosed. Due to the distinct optical signal of CDOM, I expect that remotely sensed ocean color at high resolution $(1 \mathrm{~km})$ could be interpreted in terms of salinity. Other studies have used simple linear and multiple linear algorithms to relate ocean color data from MODIS-Aqua to salinity (Ahn, 2008; Palacios et al., 2009). The relationships in these studies relate inherent optical properties such as absorption coefficients to salinity by assuming conservative mixing. However, CDOM can be created and destroyed in estuarine and coastal waters, so the relationship between CDOM optical properties and salinity is variable in space and time (Chen, 1999; Del Vecchio and Blough, 2004). I believe that salinity can be estimated from an apparent optical property such as reflectance rather than first deriving an inherant optical property such as CDOM absorption.

The purpose of this study is to estimate salinity from ocean color data at 1 $\mathrm{km}$ resolution in the coastal Mid-Atlantic region including the Chesapeake, Delaware, and Hudson Estuaries. To accomplish this, I paired in situ salinity values with MODIS-Aqua satellite data along with other environmental variables such as tides, bathymetry, SST, chlorophyll-a, stream flow, and year day. Neural network fitting routines that account for space and time variation were used to generate a relationship between these environmental variables, ocean color, and salinity. The strength of this approach is that there is no need to assume CDOM is a conservative tracer, which is not always true (Chen and Gardner, 2004). Also, unlike other approaches that first derive an inherent optical property for salinity prediction (Ahn, 2008; Palacios et al., 2009), my approach is to use apparent optical properties to predict salinity. This thesis describes the development and validation of a neural network approach for estimating 
salinity in the Mid-Atlantic shelf. The resulting regional maps of surface salinity are used to discuss spatial and temporal variability as well as trends in salinity. I present a new perspective on the relationship between salinity and remotely sensed ocean color in the Mid-Atlantic. Seasonal climatologies based on the models were then compared to existing climatologies from the National Oceanographic Data Center (NODC). While my climatologies are significantly fresher than the NODC climatologies, my in situ training data are also significantly fresher which explains the bias in my models and shows the need for more highly resolved salinity climatologies in coastal regions. 


\section{Chapter 2}

\section{METHODOLOGY}

\subsection{In situ Environmental Data}

I collected in situ data from a variety of different sources and compiled them into a single dataset. Salinity data were collected from four research vessels over a period of six years (2003-2008). The research vessels were the R/V Cape Henlopen, R/V Hugh R. Sharp, R/V Cape Hatteras and the R/V Oceanus. Each of these research vessels had an onboard surface mapping system (SMS) that regularly collected data from the sea surface while the ship was underway. The SMS data included salinity (psu), SST $\left({ }^{\circ} \mathrm{C}\right)$, time (GMT), and position. I was not able to control for the variability in SMS sensor depths on the hull ( 1-2 m depth) or the hull specific mixing effects on the ocean surface. This is an unknown source of error in this analysis. The data collected over the six-year period span the Chesapeake, Delaware, and Hudson Estuaries as well as the surrounding coastal ocean of the Mid-Atlantic (Figure 2.1A). Bathymetry data with a cell size of 6 seconds ( $145 \mathrm{~m} \mathrm{E/W,} 185 \mathrm{~m}$ N/S) were obtained from the National Geophysical Data Center's US coastal relief model (http://www.ngdc.noaa.gov/mgg/gdas/gd_designagrid.html). I matched the bathymetry grid with in situ salinity data by calculating the great circle distance between them (average distance $\sim 90 \mathrm{~m}$ ). Tide data were retrieved from the Lewes, DE tide station ( $38^{\circ} 46.9^{\prime} \mathrm{N}, 75^{\circ} 07.2^{\prime} \mathrm{W}$ ) via NOAA’s Tides Online data archive

(http://tidesonline.nos.noaa.gov/). Data were obtained for the years 2003-2008 and 
contained mean lower low water height (m) and time (GMT). Tide data was matched to salinity data by nearest time. This was done for the Delaware Bay model only. River outflow data were acquired from the USGS National Water Information System (http://waterdata.usgs.gov/nwis/rt). River outflow data included daily mean discharge $\left(\mathrm{ft}^{3} / \mathrm{s}\right)$ for six stream gauges from 2002-2009. The stream gauges were located in the Mohawk River at Cohoes, NY (01357500), the Hudson River at Fort Edwards, NY (01327750), the Delaware River at Trenton, NJ (01463500), the Schuylkill River at Philadelphia, PA (01474500), the Susquehanna River at Conowingo, MD (01578310), and the Potomac River near Washington DC (01646500). These gauges were chosen because they were the closest to their respective bays and beyond the effect of tides. I used the stream gauge data for two purposes. The first was to test stream flow as a potential predictor of salinity in my neural network models. For this I matched stream flow with in situ salinity by nearest time. The second was to compare the predictions of one of my salinity models with stream flow to see if there were any general changes in salinity in response to stream flow. For this I averaged the salinity output of the Chesapeake regional model in an area of the bay that spans the mouth of the Potomac River ( $38.1^{\circ} \mathrm{N}$ to $37.9^{\circ} \mathrm{N}$ and $76.3^{\circ} \mathrm{W}$ to $76.2^{\circ} \mathrm{W}$, roughly 22 x $9 \mathrm{~km}$ ) and compared it to stream flow data from the Potomac River stream gauge.

\subsection{Satellite Data}

Ocean color data from the MODIS-Aqua satellite were downloaded from NASA's Ocean Color website (http://oceancolor.gsfc.nasa.gov/, reprocessing 1.1). Daytime data were collected from mid-2002 to 2009 and processed using the SeaWiFS Data Analysis System (SeaDAS). Data were downloaded as level-2 
standard-suite products. Using standard SeaDAS routines, level-2 data were spatially binned to an equal-area grid at $1 \mathrm{~km}$ and transformed into geophysical standard mapped images (SMIs). These data included position, chlorophyll- $a\left(\mathrm{mg} \mathrm{m}^{-3}\right)$, normalized water-leaving radiance $\left(\mathrm{W} \mathrm{m}^{-2} \mathrm{sr}^{-1}\right)$, daytime sea surface temperature $\left({ }^{\circ} \mathrm{C}\right)$ and the time of the satellite pass (GMT). The normalized water-leaving radiance was for six wavelengths; $\mathrm{nLw}_{412}, \mathrm{nLw}_{443}, \mathrm{nLw}_{488}, \mathrm{nLw}_{531}, \mathrm{nLw}_{551}$, and $\mathrm{nLw}_{667} \mathrm{~nm}$. I also computed three band ratios ( $\mathrm{nLw}_{412} / \mathrm{nLw}_{551}, \mathrm{nLw}_{443} / \mathrm{nLw}_{551}$, and $\left.\mathrm{nLw}_{488} / \mathrm{nLw}_{551}\right)$ that acted as proxies for the spectral shape of the normalized water-leaving radiance. These ratios capture the changes in spectral shape in the blue-green portion of the spectrum, which is where the most changes in reflectance are expected from CDOM-heavy freshwater input. Band ratios have been successfully used before in other remote sensing applications (Ahn, 2008; O'Reilly et al., 1998).

\subsection{Satellite Matches}

I matched in situ salinity data to MODIS-Aqua over flights within a $2 \mathrm{~km}$ radius and 12 hour window (6 hours before and after, or within a tidal cycle). This maximized matched satellite data coverage while keeping the satellite data close to the in situ measurement. Satellite data that fell within the $2 \mathrm{~km}$ radius were averaged so that there was one unique set of values for each salinity measurement. Due to the high temporal frequency of in situ salinity data (roughly every 10 seconds), multiple in situ salinity measurements that matched the same satellite data were averaged to give one unique salinity measurement per satellite-matched pixel. The Mid-Atlantic was then subdivided into three sub-regions: the Chesapeake, Delaware and Hudson Estuaries. Figure 2.1B shows the location of the satellite-matched salinity records as well as the 
subset regions. The temporal distribution of the satellite-matched salinity data peaked in late winter/early spring and late summer/early fall (Figure 2.2).

\subsection{Neural Network Construction}

A neural network is a non-linear fitting routine that uses logical switches (nodes) rather than smooth equations to relate two or more variables. I used the nnet function (Venables, 2002) in the statistical program R (R Development Core Team, 2009). The goal was to find a relationship between salinity and an unknown combination of 17 predictors for each of the four regions (Mid-Atlantic, Chesapeake, Delaware, and Hudson). The predictors were longitude, latitude, chlorophyll- $a$, SST, year day, depth, stream flow, tides, normalized water-leaving radiance (6 wavelengths), and normalized water-leaving radiance ratios (3 ratios). Each neural network requires a training set of data on which the neurons “learn” how the salinity at the surface relates to the other environmental parameters and ocean color. The networks were trained on a random $50 \%$ of the data and analyzed for how well they could predict the other $50 \%$ based on the RMS error. With 17 predictors, there are 131,071 unique combinations possible $\left(2^{17}-1\right)$. Initial tests showed that any fewer than 7 initializing parameters produced unfavorable RMS errors ( $>4$ psu). Therefore, to reduce the number of possible neural networks to construct, I used principle component analyses (PCA) on the four regions to determine which in situ or satellite data were most correlated and least correlated with salinity in each region. The top seven PCA correlates of salinity in each region were used to initiate the neural network model construction while the five least correlated were eliminated from model consideration. The PCA was also used to minimize the cross correlation between predictor variables, however, some cross correlation still existed between 
bands close in wavelength. Then, I systematically combined the top seven PCA correlates of salinity with every combination of the remaining five environmental predictors that were moderately correlated with salinity from our PCA analysis. Networks were tested with 25, 30, 35, and 40 nodes and allowed for multiple layers of nodes. This reduced the number of model permutations to 124 for each region. The basic form of the implemented neural network was a single layer model with inputs (normalized satellite and in situ data) going into one or more layers of neurons then to the output (salinity). From this, I determined which combination yielded the lowest RMS error with the least number of parameters.

\subsection{Climatological Data}

Seasonal quarter-degree resolution salinity climatologies were acquired from the National Oceanographic Data Center's (NODC) World Ocean Atlas Select tool (http://www.nodc.noaa.gov/OC5/SELECT/woaselect/woaselect.html). Using the optimized Mid-Atlantic model, I computed seasonal climatologies by averaging predicted salinity from 32-day rolling average satellite data for each season from 2003-2008. Following the NODC climatologies, seasons were defined by dividing the year evenly into four three-month periods; winter is from Jan-Mar, spring is from AprJun, summer is from Jul-Sept, and fall is from Oct-Dec. When averaging the predicted salinity fields to create climatologies for my grid, only those grid points that had satellite coverage $>50 \%$ for the full 6 years were included. By using rolling 32-day average satellite data for computing climatologies, weekly variability was removed, but coverage greatly increased. Climatologies were matched with the NODC quarterdegree climatologies by calculating the great circle distance between grid points. I also used my seasonal climatologies to compute the range in salinity and analyze 
interannual trends. Trends were determined by calculating linear regressions over each grid point over the 6 years. 


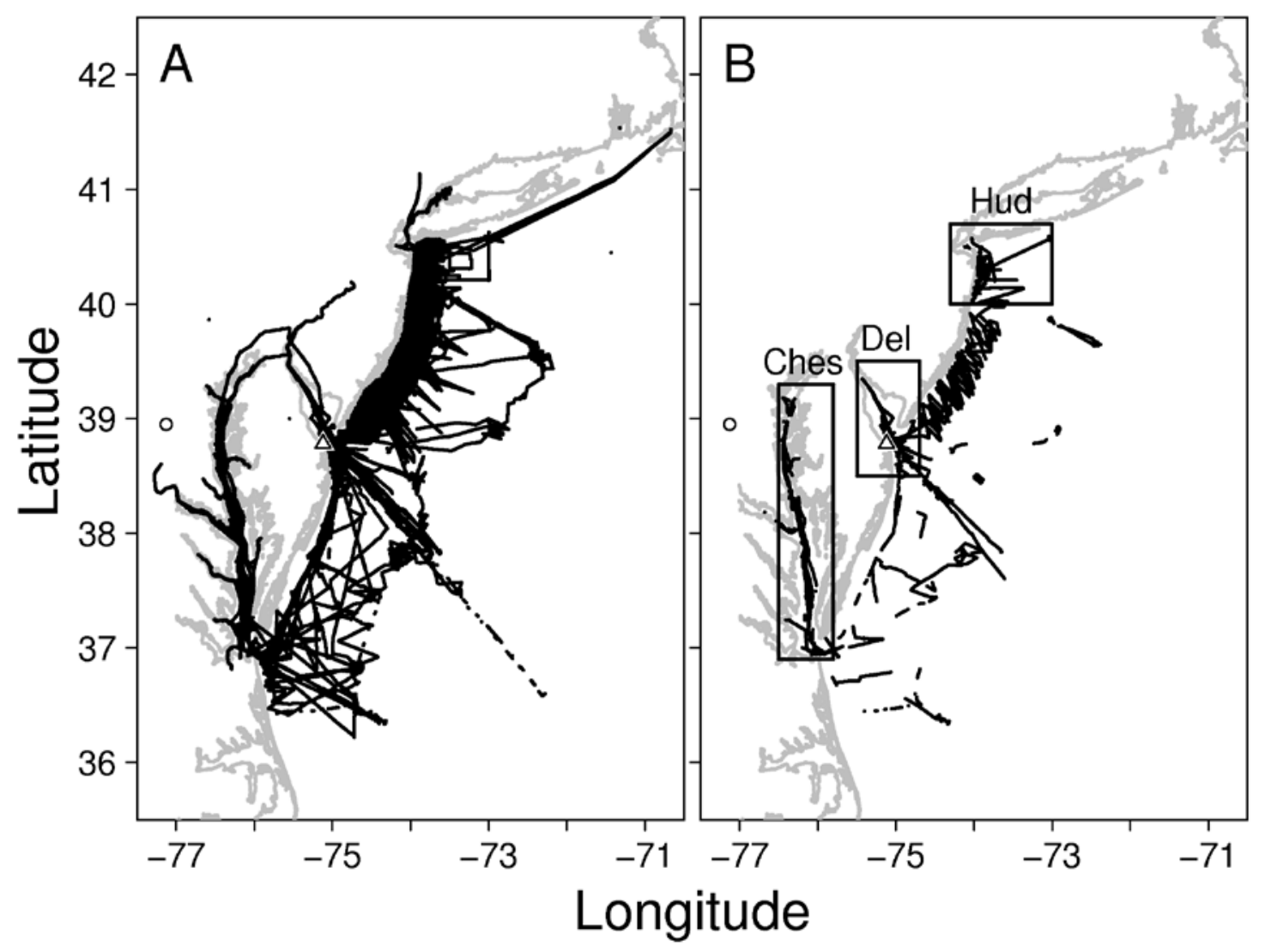

Figure 2.1: Spatial extent of in situ salinity data before (A) and after (B) satellite match-up. Boxes indicate sub-regions (from North to South:

Hudson, Delaware, Chesapeake). Also shown are the locations of the Potomac River stream gauge (open circle) and the Lewes, DE tide station (open triangle). The matched dataset contains less than $1 \%$ of the original dataset. 


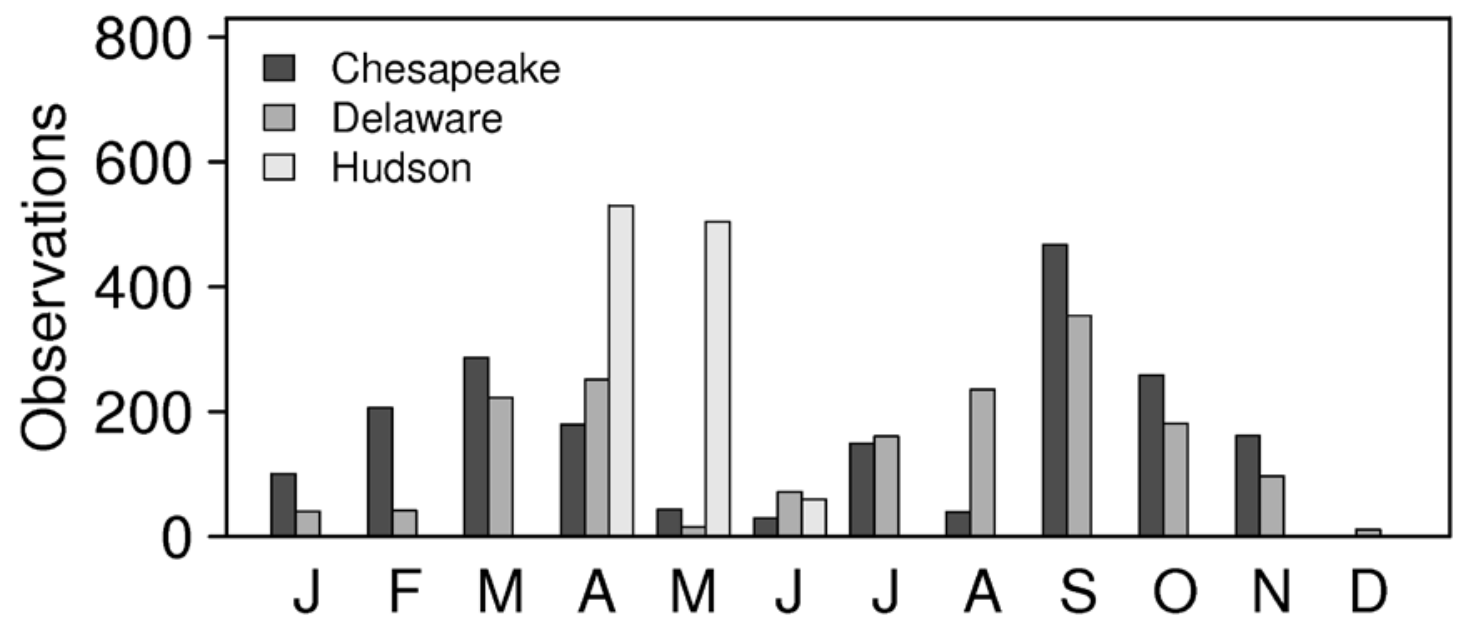

Figure 2.2: Temporal distribution of satellite-matched in situ salinity data. Data in the Delaware and Chesapeake sub-regions are collected mostly in the late winter/early spring and late summer/early fall. Data for the Hudson sub-region only span April, May and June. 


\section{Chapter 3}

\section{RESULTS}

\subsection{Spectral Analysis}

Matching in situ salinity data to satellite data resulted in 8,957, 1,917, 1,676, and 1,093 matches for the Mid-Atlantic, Chesapeake, Delaware and Hudson regions respectively. This provided adequate data to test and train models while still using relatively strict time and space matching criteria. An analysis of the water-leaving radiance and salinity in the matched dataset revealed that fresh water had lower reflectance of blue wavelengths, most likely related to the absorption of blue wavelengths by CDOM. Figure 3.1 is the spectral shape of the MODIS-Aqua reflectance spectra (spectra normalized to maximum reflectance) colored by salinity for each of the study regions. A change in spectral shape is more likely to capture the effects of CDOM than total reflectance. Maximum reflectance for low salinity water is near 500-550 nm (green reflectance) while maximum reflectance for high salinity water is 400-450 nm (blue reflectance). This can also be interpreted as the proportionally higher absorption of blue wavelengths in fresher waters. This relationship exists for every region of this dataset, but varies slightly due to potential differences between estuaries. It is not known if this variability is estuary specific or a sampling artifact due to cloud cover and estuary size. For example, the Chesapeake is much larger than the Hudson or Delaware Estuaries; therefore I was more likely to get satellite matches with fresh water in the Chesapeake Estuary. 
Variation in spectral shape between sub-regions is probably due to inconsistent data coverage in space and time. For example, the Chesapeake sub-region contained the most freshwater, satellite-matched in situ salinity measurements (Table 3.1) and therefore has more examples of reflectance spectra that are strongly influenced by blue light absorbing constituents (Figure 3.1B). In contrast, the Delaware and Hudson sub-regions did not have as many fresh water matches due to poor satellite coverage in the fresh portions of the Delaware and Hudson sub-regions (Figures 3.1C, 3.1D). Although the optical properties of the in-water constituents most likely differ between estuaries the general trend of fresher water reflecting less blue light is evident in each sub-region.

\subsection{Neural Network Predictions}

Empirical testing of neural network salinity predictions showed that only ocean color data, SST, and position were necessary for salinity predictions. Depth, tides, river flow, and year day did not increase the predictive power of the neural networks based on the negligible changes in RMS error between model trainings and visual inspection of salinity maps as a "reality check." The input variables of the four models with the lowest RMS and most accurate prediction of salinity are in Table 3.2. The RMS errors recorded for each model are: Mid-Atlantic $=2.29$ psu, Chesapeake $=$ 1.72 psu, Delaware $=1.97$ psu, Hudson $=1.40$ psu. By comparison, the RMS errors of a random null model (i.e. ability of randomized satellite-matched in situ salinity data to predict itself) were much larger: Mid-Atlantic $=10.08 \mathrm{psu}$, Chesapeake $=8.70 \mathrm{psu}$, Delaware $=6.09$ psu, Hudson $=4.87$ psu. I also performed sensitivity analyses on each model by adding random noise $( \pm 5 \%$ ) to each predictor in the models. These analyses revealed that all models were most sensitive to the position (especially 
longitudinal), while changing other parameters negligibly changed the RMS. The Delaware and Hudson model used 30 nodes, the Mid-Atlantic model used 35, and the Chesapeake used 40. Model II regression analyses of predicted salinity versus satellite-matched in situ salinity show the salinity models generally over-predict salinity in fresher areas (Figure 3.2). The Chesapeake model had the most consistent prediction of salinity compared to available in situ data $\left(\mathrm{R}^{2}=0.9, \mathrm{p}<0.01\right)$. As an additional check, I compared salinity predictions from the Chesapeake Bay model with stream flow data collected from the stream gauge in the Potomac River near Washington DC (01646500) to confirm that my model predictions were showing the same general patterns as large stream flow events (Figure 3.3). Because of frequent cloud cover in the Chesapeake, I used a 32-day rolling average of satellite predicted salinity and compared it with a 32-day rolling average of stream flow near the Potomac River. This comparison showed there is a general response in my salinity model to freshwater influx events, however the correlation between stream flow and predicted salinity was weak $\left(\mathrm{R}^{2}=0.2, \mathrm{p}<0.01\right)$. What is not considered here is the episodic nature of stream flow, and the unknown time lag between the stream gauge and the area of the Chesapeake analyzed. Figure 3.3 shows that time lag is not the reason for a low correlation. Rather, the low correlation seems to be related to a time between 2003 and 2005 when stream flow was high, but there was not a large corresponding drop in salinity.

\subsection{Climatological Analyses}

I used my models to create seasonal climatologies for the Chesapeake, Delaware and Mid-Atlantic regions based on MODIS-Aqua satellite images. Since the satellite-matched in situ data in the Hudson sub-region was temporally skewed to the 
spring, I excluded making climatologies for that region (Figure 2.2). Climatologies were broken up into 4 seasons (Jan-Mar, Apr-Jun, July-Sep, and Oct-Dec). The four seasonal climatologies for the Mid-Atlantic region are in Figure 3.4 and emphasize the change between 25-30 psu. The vast majority of the training data were nearshore, so I limited salinity predictions to within $50 \mathrm{~km}$ of the coast. The satellite-based climatologies show that winter and fall have larger areas of fresh water than spring and summer. Comparing these Mid-Atlantic satellite-based climatologies to the NODC climatologies using model II regression revealed that my seasonal climatologies were significantly fresher than the NODC climatologies for all seasons (Figure 3.5). There were 57, 58, 57, and 55 matches between our satellite-based climatologies and NODC climatology grid points for comparison for the winter, spring, summer and fall seasons respectively. Within the Delaware and Chesapeake bays, there were only 7 matches for winter, spring, and fall and 8 matches for summer. This is because the NODC salinity climatology is a quarter degree grid, and has few points inside the Delaware and Chesapeake bays. Maximum differences between matches within the estuaries were as high as 9 psu for winter, 5 psu for spring, 8 psu for summer and 9 psu for fall. In all seasons and regions except the spring in Chesapeake Bay, my satellite-based climatology was fresher than the NODC climatology. This is likely because the in situ data that my models were trained on is also significantly fresher than the NODC climatologies. RMS errors between my climatologies and the NODC climatologies were between 1.89 and 3.91 psu and mean differences were between -3.02 and 0.16 (Table 3.3).

Using the satellite-based seasonal climatologies, I calculated the range in salinity for each season by taking the maximum value for each grid point and 
subtracting the minimum value over the 6 years. Figure 3.6 shows which areas of the continental shelf were similar from season to season and which areas were different. There are relatively high differences in salinity between winters throughout the MidAtlantic. Between spring seasons there are high differences localized to regions influenced by river plumes. Between summers and falls there are few differences in salinity across the region except for the Chesapeake Bay during the fall indicating that between season differences are smallest in the summer.

In the same manner, seasonal trends in salinity from 2003-2008 were calculated using linear regression models between grid points over all 6 years. Significant trends in salinity are defined as those grid points that had slopes with $\mathrm{p}<$ 0.05 for the 6 years analyzed. Most grid points show no significant trends in salinity, however there were significant trends in each season overall (Figure 3.7). Winter shows a decreasing trend in salinity off the coast of southern New Jersey and Long Island. The spring shows the same decreasing trend off Long Island, but also a slight increase near the mouth of the Chesapeake Bay. Summer shows very small areas of increasing salinity off the coast of Long Island and in the Chesapeake Bay as well as a decrease in salinity along the Delaware, Maryland and Virginia coast. Fall has mostly increasing salinity trends in the Chesapeake Bay and other small areas off the coast of Long Island. 


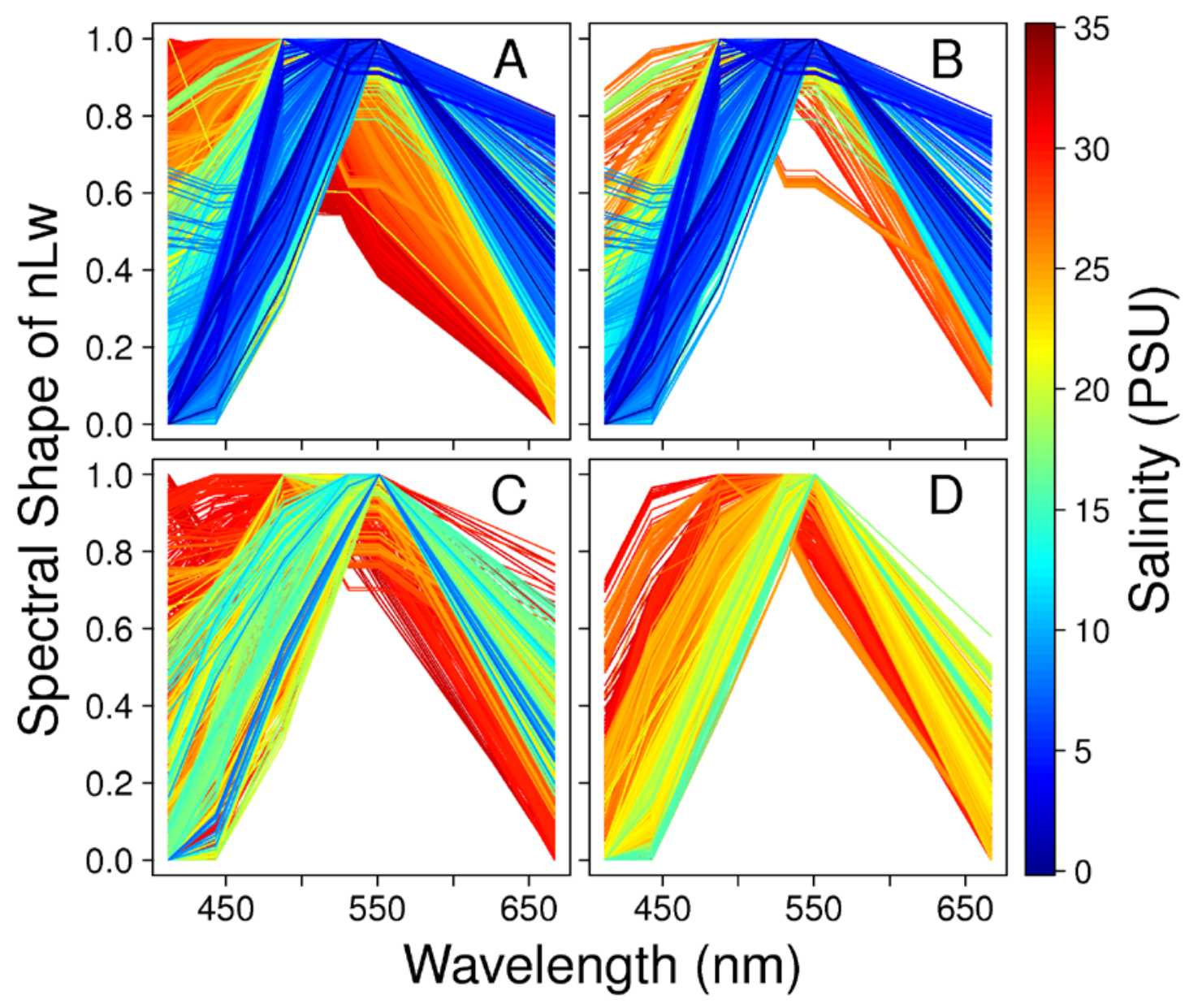

Figure 3.1: Spectral shape of water-leaving for the six wavelengths from MODIS-Aqua for the (A) Mid-Atlantic, (B) Chesapeake, (C) Delaware, and (D), Hudson sub-regions. The shapes of the spectra are colored by satellite-matched in situ salinity values where red is high salinity and blue is low salinity. Low salinity spectra have peak reflectance in the green wavelengths, while high salinity spectra have peak reflectance in blue wavelengths. 
Table 3.1: Range and mean of satellite-matched in situ salinity data.

\begin{tabular}{llll}
\hline Region & Minimum & Maximum & Mean \\
\hline Mid-Atlantic & 0.077 & 34.872 & 26.769 \\
Chesapeake & 0.077 & 32.764 & 15.783 \\
Delaware & 7.501 & 32.305 & 27.452 \\
Hudson & 15.666 & 32.202 & 26.069 \\
\hline
\end{tabular}

Table 3.2: Input parameters of optamized neural networks. The columns represent latitude, longitude, sea surface temperature $\left({ }^{\circ} \mathrm{C}\right)$, and normalized water-leaving radiance wavelengths and wavelength ratios at specified magnitudes in (nm). The rows indicate which model they are in.

\begin{tabular}{lcccccccccccc}
\hline & \multicolumn{10}{c}{ Parameter } & & \multicolumn{10}{c}{} \\
\cline { 2 - 13 } Model & Lat & Lon & SST & $\mathbf{4 1 2}$ & $\mathbf{4 4 3}$ & $\mathbf{4 8 8}$ & $\mathbf{5 3 1}$ & $\mathbf{5 5 1}$ & $\mathbf{6 6 7}$ & $\mathbf{4 1 2}^{\dagger}$ & $\mathbf{4 4 3}^{\dagger}$ & $\mathbf{4 8 8}^{\dagger}$ \\
\hline Mid-Atlantic & & $\mathrm{X}$ & $\mathrm{X}$ & $\mathrm{X}$ & & & $\mathrm{X}$ & $\mathrm{X}$ & $\mathrm{X}$ & $\mathrm{X}$ & $\mathrm{X}$ & $\mathrm{X}$ \\
Chesapeake & $\mathrm{X}$ & $\mathrm{X}$ & $\mathrm{X}$ & $\mathrm{X}$ & $\mathrm{X}$ & & & & & $\mathrm{X}$ & $\mathrm{X}$ & $\mathrm{X}$ \\
Delaware & $\mathrm{X}$ & $\mathrm{X}$ & $\mathrm{X}$ & $\mathrm{X}$ & & $\mathrm{X}$ & $\mathrm{X}$ & $\mathrm{X}$ & $\mathrm{X}$ & $\mathrm{X}$ & $\mathrm{X}$ & $\mathrm{X}$ \\
Hudson & $\mathrm{X}$ & $\mathrm{X}$ & $\mathrm{X}$ & & & & & $\mathrm{X}$ & $\mathrm{X}$ & $\mathrm{X}$ & $\mathrm{X}$ & $\mathrm{X}$ \\
\hline
\end{tabular}

${ }^{\dagger}$ Wavelength ratios (the wavelength specified divided by $\mathrm{nLw}_{551}$ ).

Table 3.3: RMS and mean difference between NODC climatology and satellitebased Mid-Atlantic climatology.

\begin{tabular}{lll}
\hline Season & RMS & Mean Difference \\
\hline Winter & 3.91 & -2.93 \\
Spring & 1.89 & 0.16 \\
Summer & 2.69 & -1.33 \\
Fall & 3.87 & -3.02 \\
\hline
\end{tabular}




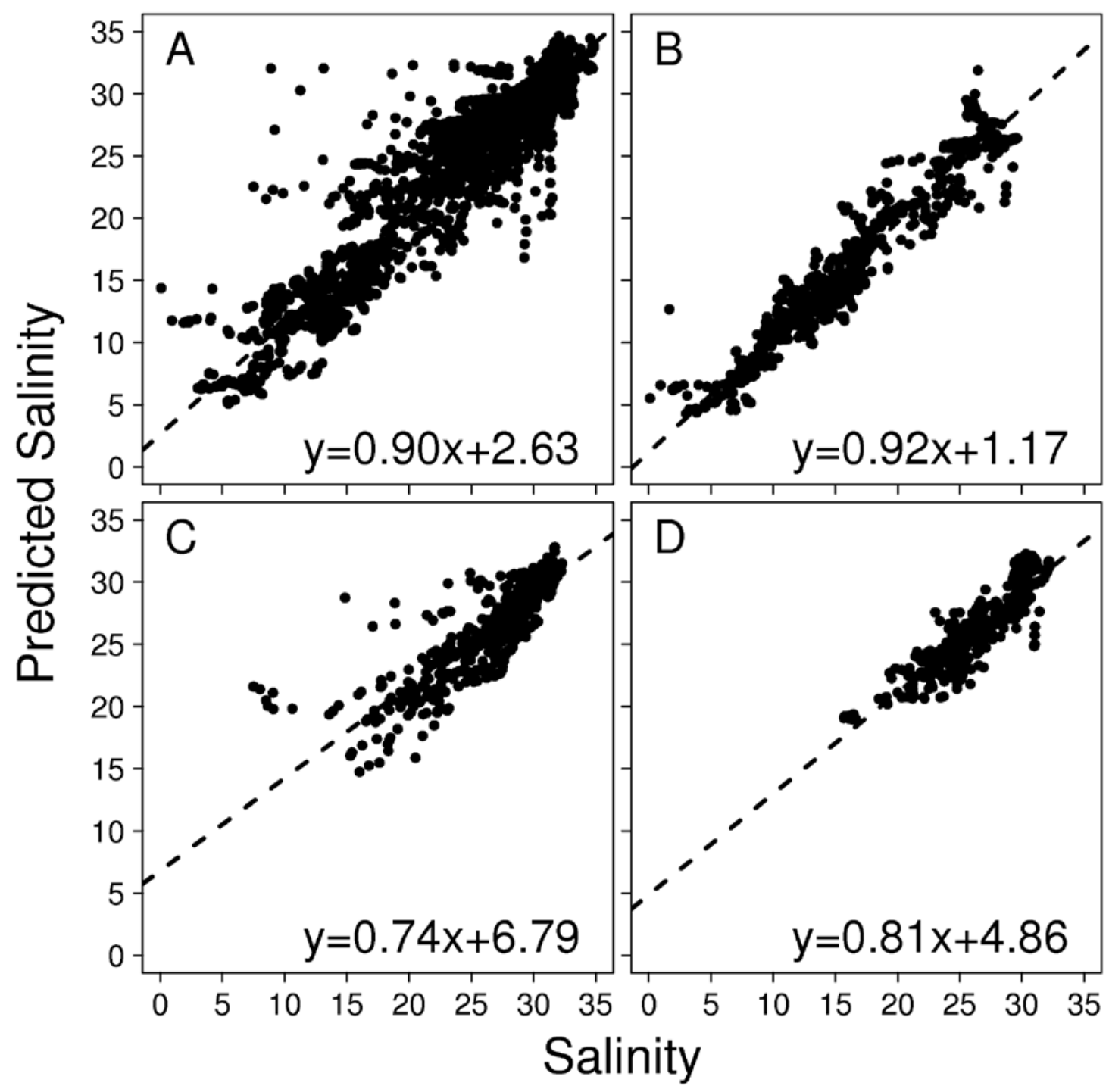

Figure 3.2: Model II regression of satellite-matched in situ salinity vs. model predicted salinity in the (A) Mid-Atlantic, (B) Chesapeake, (C) Delaware, and (D), Hudson sub-regions. All of the regressions are significant $(p<0.01)$. All of the models over predict salinity. The RMS errors for each are as follows: Mid-Atlantic $=2.29 \mathrm{psu}$, Chesapeake $=1.72 \mathrm{psu}$, Delaware $=1.97 \mathrm{psu}$, Hudson $=1.40 \mathrm{psu}$. 


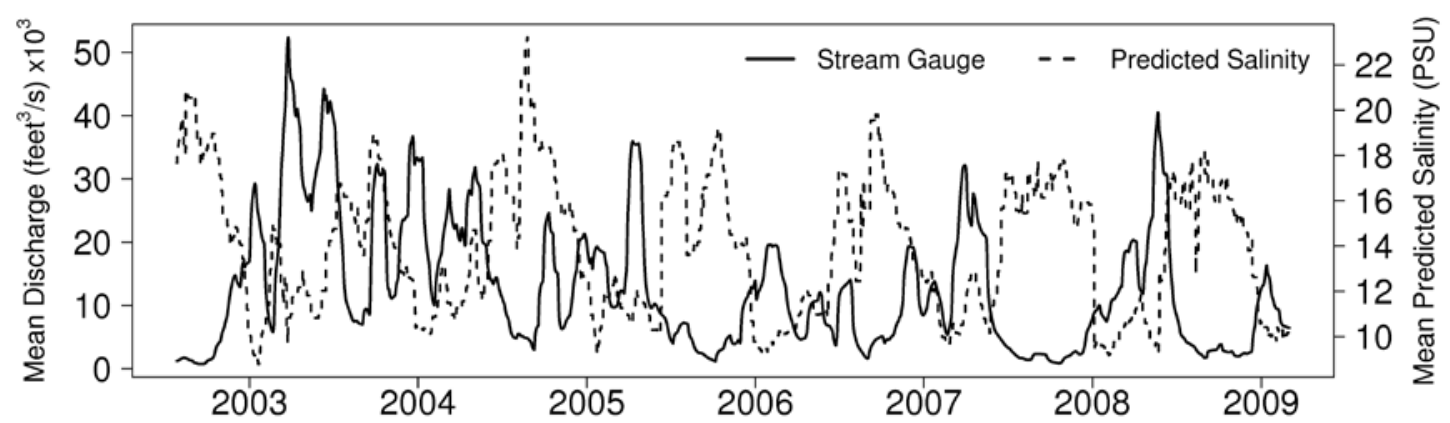

Figure 3.3: Time series of rolling 32-day averaged stream flow in the Potomac River near Washington DC (gauge 01646500) and 32-day averaged salinity at the mouth of the Potomac River (22 x $8.75 \mathrm{~km}$ box). There is a significant inverse pattern between stream flow and salinity, however the correlation between them is low $\left(R^{2}=0.2, p<\right.$ 0.01). 


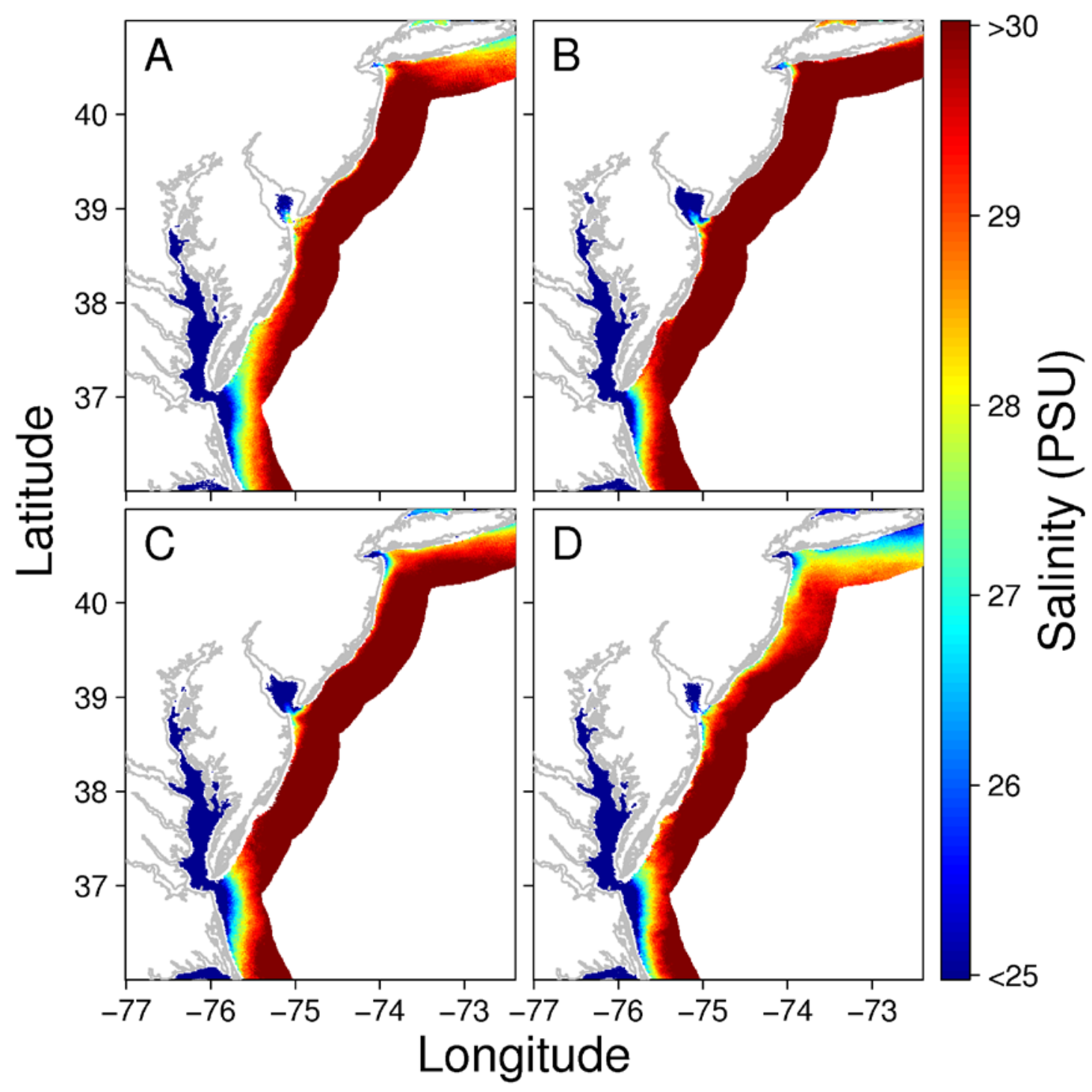

Figure 3.4: Seasonal salinity climatologies for (A) winter, (B) spring, (C) summer, and (D) fall for the Mid-Atlantic model up to $50 \mathrm{~km}$ offshore. All seasons show characteristic coastally trapped river plumes. Winter and fall are generally fresher. Climatologies are mapped between 25 and 30 psu to emphasize differences between seasons. 


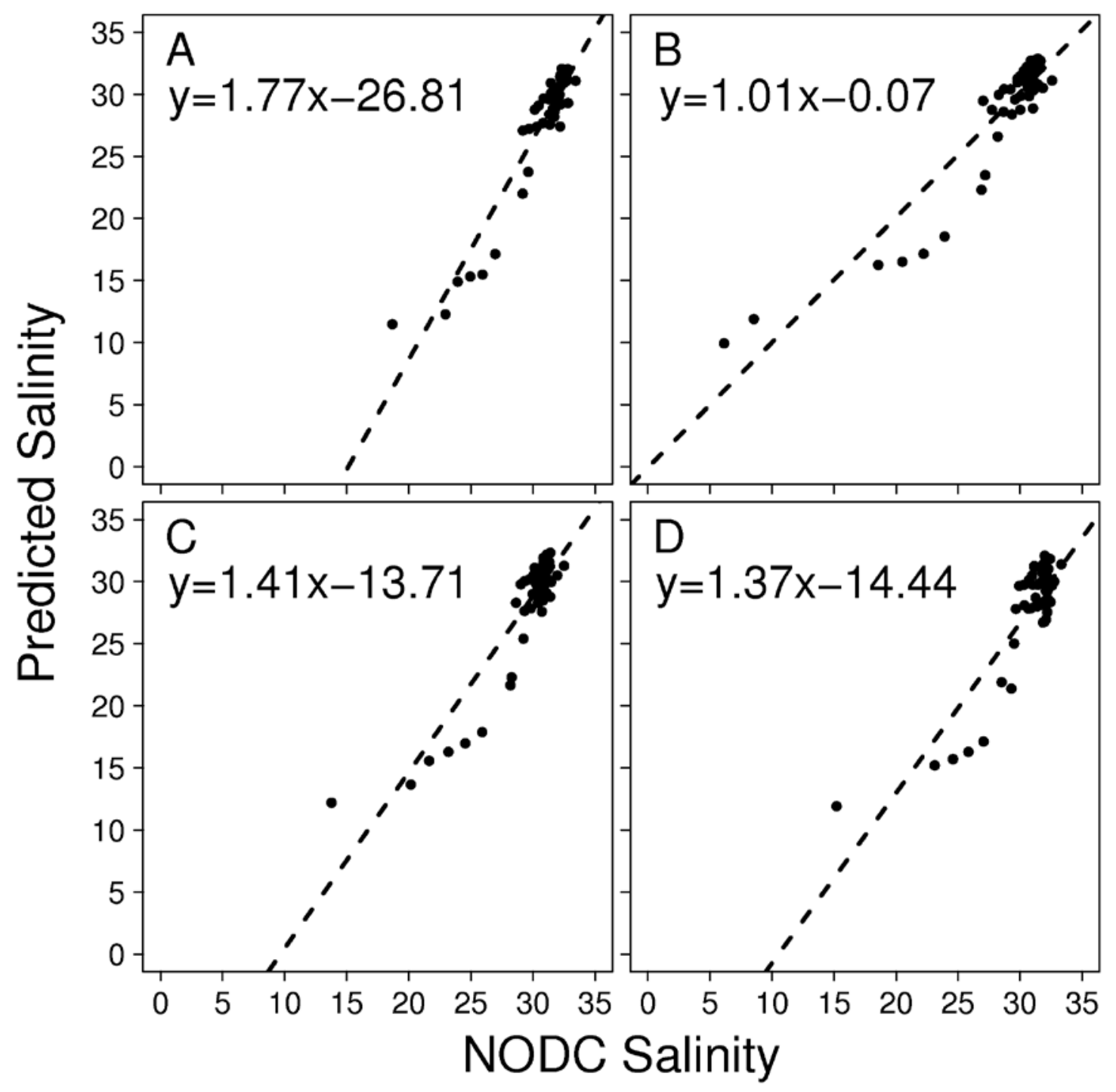

Figure 3.5: Model II regression between the Mid-Atlantic model climatologies and the NODC quarter-degree resolution climatologies for (A) winter, (B) spring, (C) summer, and (D) fall. Our satellite-based salinity models are significantly fresher than the existing climatologies. RMS errors for each are as follows: winter $=3.91 \mathrm{psu}$, spring $=1.89 \mathrm{psu}$, summer $=2.69 \mathrm{psu}$, fall $=3.87 \mathrm{psu}$. 


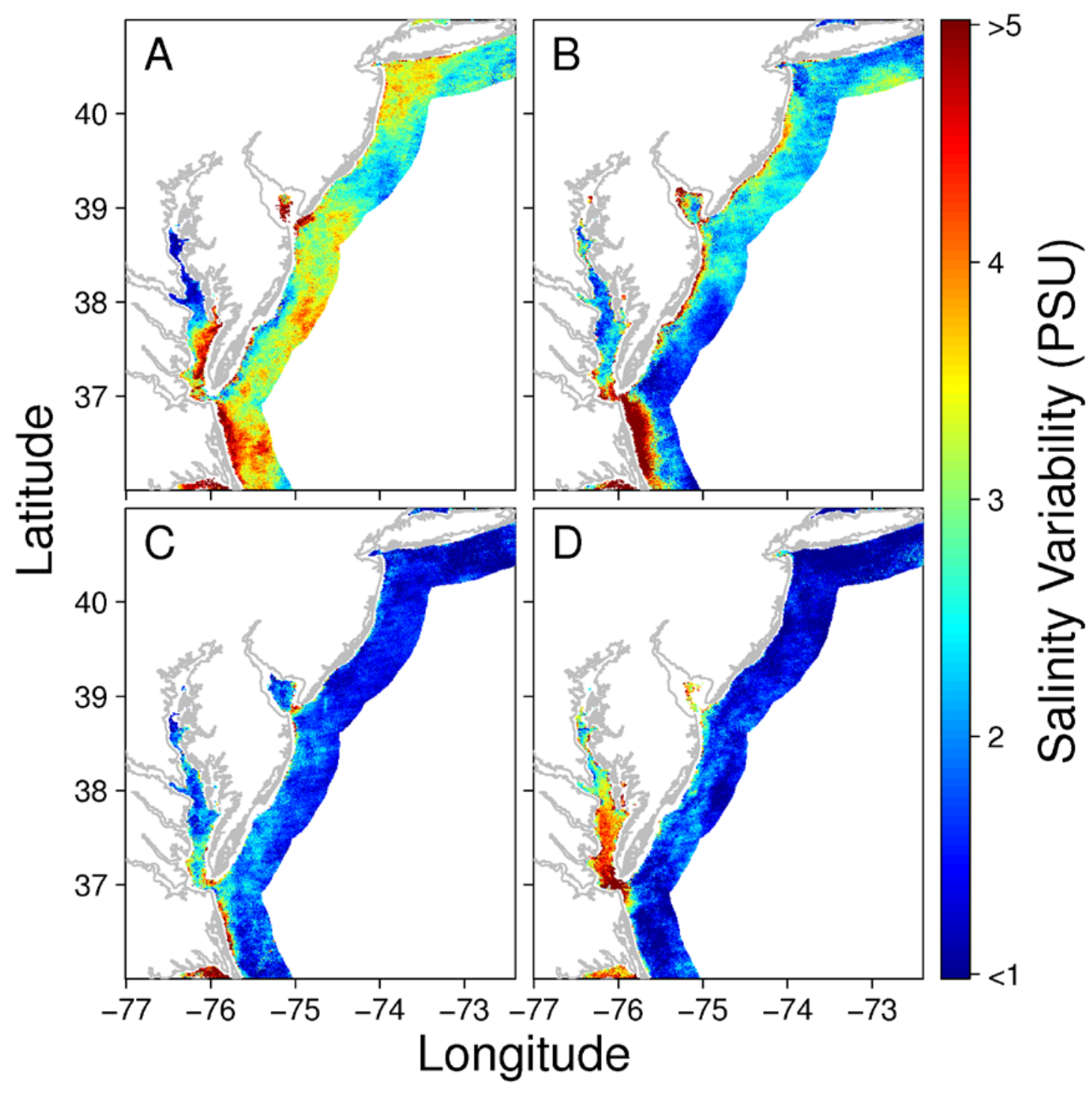

Figure 3.6: Between-season salinity ranges for (A) winter, (B) spring, (C) summer, and (D) fall calculated from the Mid-Atlantic model climatologies. Ranges were calculated by subtracting the minimum salinity value from the maximum salinity value for each grid point for the 6 years analyzed (2003-2008). Winter (A) has the largest salinity difference of the four seasons throughout the Mid-Atlantic while summer $(C)$ has the least. 


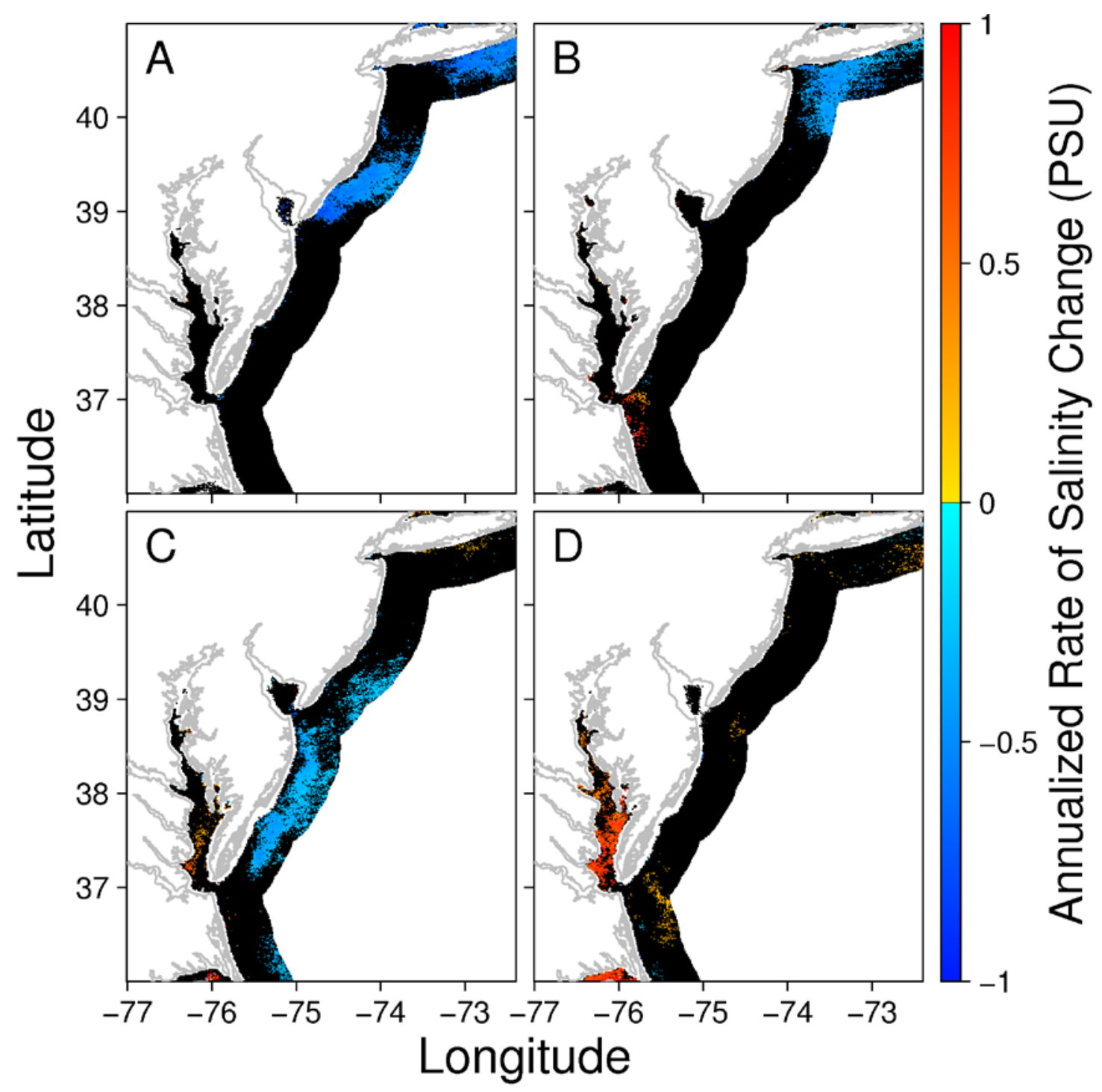

Figure 3.7: Annualized rate of salinity change for (A) winter, (B) spring, (C) summer, and (D) fall calculated from the Mid-Atlantic model climatologies. Annualized rates of change were calculated using linear regression models on each grid point for the 6 years analyzed (2003-2008). Only significant slopes $(p<0.05)$ at each grid point were colored. Positive slopes are red and negative slopes are blue. Insignificant slopes are black to show the model domain. Trends in salinity range from -1 to 1 psu. 


\section{Chapter 4}

\section{DISCUSSION}

In this study, I present a novel approach for predicting coastal salinity from ocean color data measured by the MODIS-Aqua satellite. Neural networks are used to create a statistical relationship between ocean color, SST, position and salinity without depending on the derivation of an inherent optical property. With this approach, there is no need to assume that CDOM mixing (or other optically active tracers of salinity such as detritus) is conservative such as in models proposed by Ahn, 2008 and Palacios et al., 2009. Spectral analyses of satellite-matched salinity data showed that there is a distinct relationship between in situ salinity and ocean color measured by MODIS-Aqua in the Mid-Atlantic coastal ocean. In general, fresh water proportionally reflects more light toward the red end of the visible spectrum, while high salinity water reflects proportionally more light toward the blue end of the visible spectrum. This is most likely due to the presence of CDOM and the optical properties of other in-water constituents originating from land that absorb light strongly in the blue portion of the spectrum. This relationship allows for the direct use of ocean color in the Mid-Atlantic and its estuaries to predict nearshore salinity.

SST is also an important salinity predictor in my models. In the summer, estuaries warm faster than the coastal ocean. The comparatively warm waters of the estuaries are a signal for fresh water. In the winter, estuaries cool faster than the coastal ocean, making the comparatively cool water a low salinity signal. Some river 
plumes also contain thermal signatures of their own, which could relate back to salinity.

Finally, my models show that position is important for predicting salinity. This is likely because of the east-west salinity gradient observed off the Mid-Atlantic coast from coastally trapped river plumes and the western freshwater sources (Chant et al., 2008) and north-south salinity gradients observed within estuaries, especially the Chesapeake and Delaware (Bulger et al., 1993). The need for position constrains the application of these models to the Mid-Atlantic region, making these specific models non-applicable to other areas. However, the inclusion of position as strong predictors of salinity suggest that location specific processes in the Mid-Atlantic are important for relating remotely sensed variables with salinity. These processes may include local mixing, local creation and destruction of CDOM and proximity to specific types of land cover such as salt marshes or agriculture.

Overall, my models perform well with RMS errors much less than the null models and the natural range of the system they were predicting. However, the Model II slopes in Figure 3.2 indicate these models are slightly over-predicting salinity in comparison to in situ salinity data. I also withheld a year of data in the training of the models to see how well the models perform predicting a year's worth of unseen data. Overall, the models did not perform as well. This indicates that the satellite-matched in situ salinity data does not yet capture the full variability of salinity in this region. More satellite-matched in situ salinity is needed to improve these model predictions.

Comparing the Chesapeake Bay model with stream flow from the Potomac River revealed that there is a consistent pattern between salinity and stream flow in the bay, but it cannot be used as a predictive pattern. This may be why stream flow was 
statistically eliminated as an input for model development . Factors for this could include the size of the watershed considered, evaporation, and the local distribution of precipitation (Austin, 2002). Precipitation falling downstream of the gauge or even over the bay could contribute to any disconnection observed between salinity and the stream flow observed at any given stream gauge.

My seasonal salinity climatologies followed some known features of the MidAtlantic coastal ocean. The first noticeable similarity between the climatologies is the east-west salinity gradient, especially at the mouths of the estuaries in the winter and fall (Figure 3.4). Other similarities include the coastally trapped river plumes and the freshwater bulge out of the Hudson Estuary (Chant et al., 2008). In the Mid-Atlantic Bight, the effect of coastally trapped river plumes can be seen along New Jersey and Long Island. Freshwater from the Hudson gets trapped along New Jersey during downwelling winds and it turns toward Long Island during upwelling winds (Chant et al., 2008). Some major differences between my climatologies are that winter and fall have larger areas of fresh water than summer and spring and that fall has the freshest water around the Hudson Estuary.

A significant correlation exists between the NODC climatologies and my models (Figure 3.5), however my models significantly under-predict salinity compared to the NODC climatologies. After comparing the satellite-matched in situ data to the NODC climatology, I found that the in situ data was also significantly fresher. This explains why my climatologies were fresher since they are based on the satellite-matched in situ training data. In the spring, the comparison between my climatology and the NODC climatology is much better, but still an under-prediction. Besides not having many freshwater points to compare, the NODC climatologies also 
have fewer points overall and do not estimate salinity over the same range as my models. This analysis shows there is a need for better nearshore climatologies of salinity at higher resolution.

Historically, the interannual variability in salinity in the Mid-Atlantic Bight near the Gulf of Maine has been largely associated with variability in river runoff and local precipitation (Manning, 1991) (Mountain and Manning, 1994). In the coastal ocean, upwelling and downwelling winds either trap these plumes nearshore, or disperse the low salinity water over the continental shelf, adding to the interannual variability of salinity in the Mid-Atlantic Bight (Castelao et al., 2010; Ryan et al., 1999; Yankovsky and Garvine, 1998). Salinity ranges calculated from my seasonal climatologies over the 6 years also suggest that coastally trapped plumes contribute to interannual salinity variability in the coastal ocean (Figure 3.6). Variability in coastal salinity impacts the development of seasonal stratification and mixing, which influences phytoplankton productivity in the coastal zone.

Significant trends in salinity existed in all four seasons for the 6 years analyzed (Figure 3.7). The largest areas of salinity change off the coast of Long Island and New Jersey show decreasing salinity for every season except the fall. A previous study in the Mid-Atlantic Bight found that salinity in the 1990s was 0.25 psu fresher than in the 1980s (Mountain, 2003). Other studies on trends in salinity show weak, but significant correlations between the North Atlantic Oscillation Index (NAOI) and Long Island Sound salinity as well as high correlations among Mid-Atlantic Bight rivers, salinities at different shelf sections, and salinities at Long Island Sound stations (Whitney, 2010). During positive intervals of the NAO, there is a tendency for high discharge and low Long Island Sound salinity. The time of our analysis between 2003 
and 2008 had more positive NAO intervals than negative, which may suggest that my calculated trends of coastal salinity freshening are linked to a larger natural climate cycle. As longer time series of ocean salinity become available, cycles and trends in coastal salinity may be linked to large-scale climate forces. 


\section{Chapter 5 \\ CONCLUSION}

In this study I found that remotely sensed ocean color is a strong predictor of salinity in the Mid-Atlantic coastal ocean. I have shown that it is possible to estimate salinity from an apparant optical property such as reflectance. The approach I used can be transported to other regions of the world with similar coastal processes. I would not reccommend using this approach in open ocean environments as the processes controlling CDOM production are different. The models I have produced have a strong positional dependency and are restricted to the Mid-Atlantic region. As expected, the largest salinity ranges in the Mid-Atlantic are in areas around estuaries. My analyses also shows large regions of freshening in the Mid-Atlantic Bight in the winter, spring, and summer, although the mechanism for this freshening is unknown. Compared with the NODC salinity climatologies, both my in situ salinity data and my climatologies are fresher, indicating that robust nearshore salinity climatologies are needed. Future directions for this research include real-time salinity output for the Mid-Atlantic coastal ocean and incorporation and comparisons with other modeling efforts. It is likely that improvements in the temporal and spatial coverage of synoptic ocean color measurements and greater in situ salinity sampling efforts would enhance this approach. The greatest need for in situ salinity data is during the winter and in the shallow tributaries of the estuaries. These efforts would be a good opportunity to utilize AUVs. These sampling efforts must also coincide with cloud-free days to 
maximize matches with satellite data. The use of a geostationary ocean color satellite in theis region would improve our ability to match in situ salinity data to satellite data. I would suggest the re-training of this type of model be done every 3-5 years as new data for matching becomes available. I view this study as a support to the overall NASA Aquarius salinity mission by providing satellite-based nearshore salinity climatologies that are rooted in in situ observations. My seasonal salinity climatologies are available for download here: http://modata.ceoe.udel.edu/dev/egeiger/salinity_climatologies/ 


\section{Chapter 6}

\section{APPLICATION}

Since the completion of this project the NASA ocean color website has undergone a re-processing of the MODIS data. I used this method again to create a new Chesapeake Bay algorithm with similar results using remote sensing reflectance instead of normalized water-leaving radience. The Chesapeake Bay algorithm I created was implemented into NOAA's Coastwatch program for monitoring Chesapeake Bay salinity. They are producing daily salinity maps based on the current MODIS-Aqua passes as well as seven day composites. The Chesapeake Bay algorithm in use can be found here: http://coastwatch.chesapeakebay.noaa.gov/cb_salinity.html. I’ve included an example map from NOAA's website on a cloud-free day in figure 6.1. The R code and instructions for training and applying this Chesapeake Bay algorithm can be found here: http://modata.ceoe.udel.edu/dev/egeiger/NOAA_OCR$\mathrm{SSS} /$ 

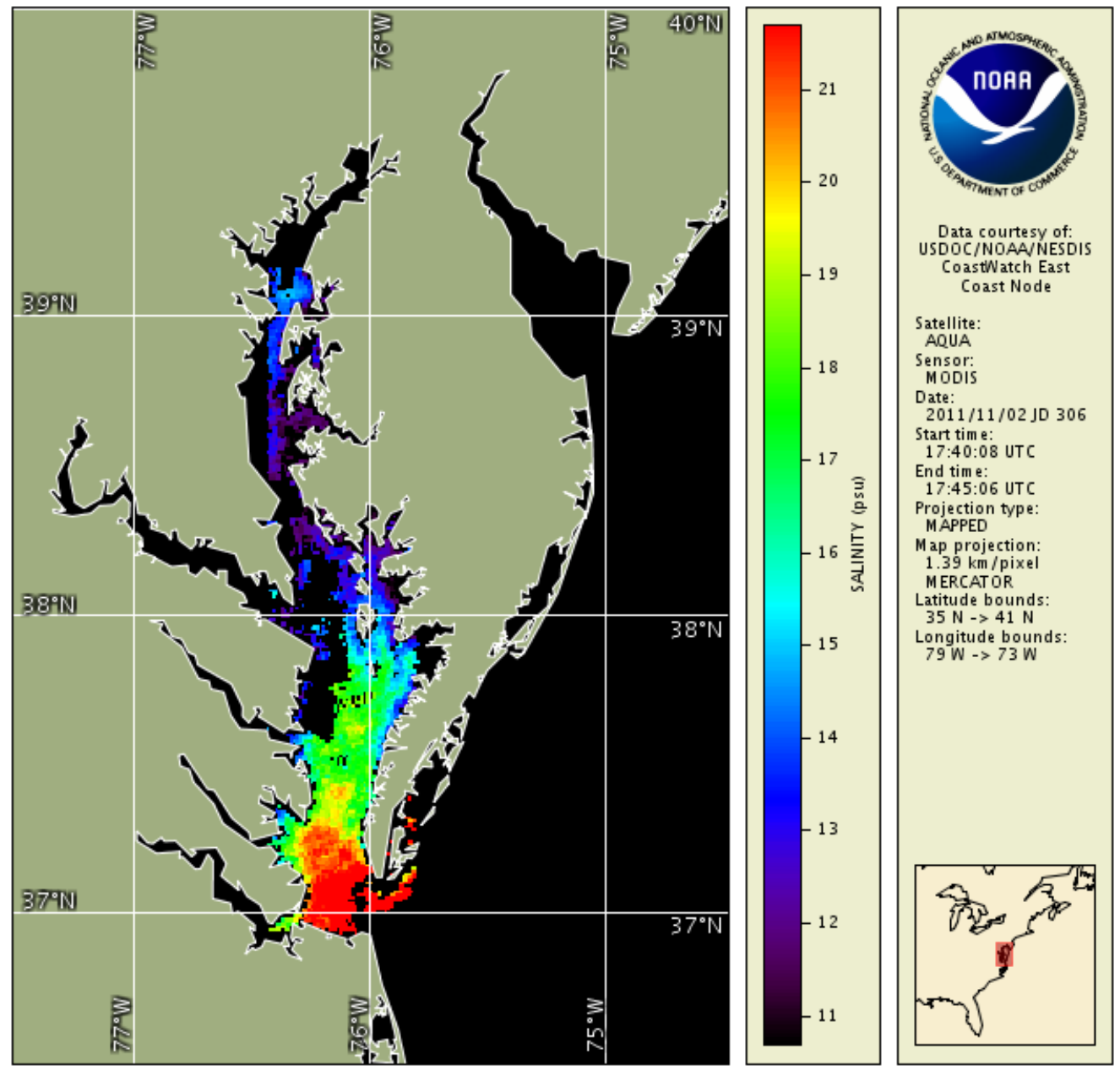

Figure 6.1: Salinity estimated from the Chesapeke Bay algorithm as seen on NOAA's coastwatch website. This image was produced on November 2nd, 2011. Salinity is in units of PSU. Red values are high salinity and blue values are low. 


\section{REFERENCES}

Ahn, Y.H., Shanmugam, P., Moon, J. E., Ryu, J. H., 2008. Satellite remote sensing of a low-salinity water plume in the East China Sea. Annales Geophysicae 26, 16.

Austin, J.A., 2002. Estimating the mean ocean-bay exchange rate of the Chesapeake Bay. J. Geophys. Res. 107, 3192.

Binding, C.E., Bowers, D.G., 2003. Measuring the salinity of the Clyde Sea from remotely sensed ocean colour. Estuarine Coastal and Shelf Science 57, 605-611.

Bowers, D.G., Harker, G.E.L., Smith, P.S.D., Tett, P., 2000. Optical properties of a region of freshwater influence (The Clyde Sea). Estuarine Coastal and Shelf Science 50, 717-726.

Brooks, K.M., 2005. The effects of water temperature, salinity, and currents on the survival and distribution of the infective copepodid stage of sea lice (Lepeophtheirus salmonis) originating on Atlantic salmon farms in the Broughton Archipelago of British Columbia, Canada. Reviews in Fisheries Science 13, 177-204.

Bulger, A., Hayden, B., Monaco, M., Nelson, D., McCormick-Ray, M. 1993. Biologically-based estuarine salinity zones derived from a multivariate analysis. Estuaries and Coasts 16, 311-322.

Castelao, R., Glenn, S., Schofield, O., 2010. Temperature, salinity, and density variability in the central Middle Atlantic Bight. J. Geophys. Res. 115, C10005.

Chant, R.J., Glenn, S.M., Hunter, E., Kohut, J., Chen, R.F., Houghton, R.W., Bosch, J., Schofield, O., 2008. Bulge Formation of a Buoyant River Outflow. J. Geophys. Res. 113, C01017.

Chen, R.F., 1999. In situ fluorescence measurements in coastal waters. Organic Geochemistry 30, 397-409. 
Chen, R.F., Gardner, G.B., 2004. High-resolution measurements of chromophoric dissolved organic matter in the Mississippi and Atchafalaya River plume regions. Marine Chemistry 89, 103-125.

Coble, P., Hu, C., Gould, J., R.W., Chang, G., Wood, A.M., 2004. Colored Dissolved Organic Matter in the Coastal Ocean: An Optical Tool for Coastal Zone Environmental Assessment and Management, Oceanography, pp. 50-59.

Del Vecchio, R., Blough, N.V., 2004. Spatial and seasonal distribution of chromophoric dissolved organic matter and dissolved organic carbon in the Middle Atlantic Bight. Marine Chemistry 89, 169-187.

Fennel, K., Wilkin, J., Levin, J., Moisan, J., O'Reilly, J., Haidvogel, D., 2006. Nitrogen cycling in the Middle Atlantic Bight: Results from a threedimensional model and implications for the North Atlantic nitrogen budget. Global Biogeochem. Cycles 20, GB3007.

Fisher, T.R., Harding, L.W., Stanley, D.W., Ward, L.G., 1988. Phytoplankton, nutrients, and turbidity in the Chesapeake, Delaware, and Hudson estuaries. Estuarine, Coastal and Shelf Science 27, 61-93.

Geiger, E.F., Grossi, M.D., Trembanis, A.C., Kohut, J.T., Oliver, M.J., 2012. Satellitederived Coastal Ocean and Estuarine Salinity in the Mid-Atlantic.

Continental Shelf Research. Accepted.

Johnson, D.R., Miller, J., Schofield, O., 2003. Dynamics and optics of the Hudson River outflow plume. Journal of Geophysical Research-Oceans 108, -.

Kinne, O., 1983. Citation Classic - the Effects of Temperature and Salinity on Marine and Brackish Water Animals .2. Salinity and Temperature-Salinity Combinations. Current Contents/Agriculture Biology \& Environmental Sciences, 22-22.

Lagerloef, G., C. Swift, LeVine, D., 1995. Sea surface salinity: The next remote sensing challenge. Oceanography 8, 44-50.

Lagerloef, G., Colomb, F.R., Le Vine, D., Wentz, F., Yueh, S., Ruf, C., Lilly, J., Gunn, J., Chao, Y., deCharon, A., 2008. The Aquarius/SAC-D Mission: Designed to Meet the Salinity Remote-Sensing Challenge. OCEANOGRAPHY 21, 68-81. 
Malone, T.C., Crocker, L.H., Pike, S.E., Wendler, B.W., 1988. Influences of River Flow on the Dynamics of Phytoplankton Production in a Partially Stratified Estuary. Marine Ecology-Progress Series 48, 235-249.

Manning, J., 1991. Middle Atlantic Bight salinity: interannual variability. Continental Shelf Research 11, 123-137.

Moline, M.A., Frazer, T.K., Chant, R., Glenn, S., Jacoby, C.A., Reinfelder, J.R., Yost, J., Zhou, M., Schofield, O., 2008. Biological responses in a dynamic buoyant river plume., Oceanography, pp. 70-89.

Monahan, E.C., Pybus, M.J., 1978. Color, Ultraviolet Absorbance and Salinity of Surface Waters Off West-Coast of Ireland. Nature 274, 782-784.

Mountain, D.G., 2003. Variability in the properties of Shelf Water in the Middle Atlantic Bight, 1977\&\#8211;1999. J. Geophys. Res. 108, 3014.

Mountain, D.G., Manning, J.P., 1994. Seasonal and interannual variability in the properties of the surface waters of the Gulf of Maine. Continental Shelf Research 14, 1555-1581.

O'Reilly, J.E., Maritorena, S., Mitchell, B.G., Siegel, D.A., Carder, K.L., Garver, S.A., Kahru, M., McClain, C., 1998. Ocean color chlorophyll algorithms for SeaWiFS. Journal of Geophysical Research-Oceans 103, 24937-24953.

Opsahl, S., Benner, R., 1997. Distribution and cycling of terrigenous dissolved organic matter in the ocean. Nature 386, 480-482.

Palacios, S.L., Peterson, T.D., Kudela, R.M., 2009. Development of synthetic salinity from remote sensing for the Columbia River plume. J. Geophys. Res. 114, C00B05.

Ryan, J.P., Yoder, J.A., Cornillon, P.C., 1999. Enhanced Chlorophyll at the Shelfbreak of the Mid-Atlantic Bight and Georges Bank during the Spring Transition. Limnology and Oceanography 44, 1-11.

Siegel, D.A., Michaels, A.F., 1996. Quantification of non-algal light attenuation in the Sargasso Sea: Implications for biogeochemistry and remote sensing. Deep-Sea Research Part Ii-Topical Studies in Oceanography 43, 321-345. 
Siegel, D.A., Michaels, A.F., Sorensen, J.C., Obrien, M.C., Hammer, M.A., 1995. Seasonal Variability of Light Availability and Utilization in the Sargasso Sea. Journal of Geophysical Research-Oceans 100, 8695-8713.

Smith, W.O., Demaster, D.J., 1996. Phytoplankton biomass and productivity in the Amazon River plume: Correlation with seasonal river discharge. Continental Shelf Research 16, 291-319.

Swift, C.T., Mcintosh, R.E., 1983. Considerations for Microwave Remote-Sensing of Ocean-Surface Salinity. Ieee Transactions on Geoscience and Remote Sensing 21, 480-491.

R Development Core Team, 2009. R: A language and environment for statistical computing. R Foundation for Statistical Computing, Vienna, Austria.

Venables, W.N., and B. D. Ripley, 2002. Modern Applied Statistics With S, 4th ed. Springer, New York.

Vodacek, A., Blough, N.V., DeGrandpre, M.D., Peltzer, E.T., Nelson, R.K., 1997. Seasonal Variation of CDOM and DOC in the Middle Atlantic Bight: Terrestrial Inputs and Photooxidation. Limnology and Oceanography 42, 674-686.

Whitney, M.M., 2010. A study on river discharge and salinity variability in the Middle Atlantic Bight and Long Island Sound. Continental Shelf Research 30, 305-318.

Wilkin, J.L., Arango, H.G., Haidvogel, D.B., Lichtenwalner, C.S., Glenn, S.M., Hedstrom, K.S., 2005. A regional ocean modeling system for the Longterm Ecosystem Observatory. Journal of Geophysical Research-Oceans $110,-$.

Yankovsky, A.E., Garvine, R.W., 1998. Subinertial Dynamics on the Inner New Jersey Shelf during the Upwelling Season. Journal of Physical Oceanography 28, 2444-2458. 